\title{
Biosafety management and pesticide use in China's Bt cotton production
}

\author{
Jikun HUANG ${ }^{\mathrm{a}, *}$, Ruijian CHEN ${ }^{\mathrm{a}, \mathrm{b}}$, Fangbin QIAO $^{\mathrm{c}, *}$, Kongming WU $^{\mathrm{d}}$ \\ a Center for Chinese Agricultural Policy, Chinese Academy of Sciences and Institute of Geographic Sciences and Natural Resource Research, China \\ ${ }^{\mathrm{b}}$ Foreign Economic Cooperation Center, Ministry of Agriculture, China \\ c China Economics and Management Academy, Central University of Finance and Economics, China \\ d State Key Laboratory for Biology of Insect Pests and Plant Diseases, Institute of Plant Protection, Chinese Academy of Agricultural Sciences, China
}

\section{A R T I C L E I N F O}

\section{Article history:}

Received 16 April 2014

Received in revised form 3 January 2015

Accepted 6 January 2015

Available online 10 January 2015

\section{JEL classification:}

Q12

Q16

013

Keywords:

Biosafety regulation

Pesticide use

Bt cotton

China

\begin{abstract}
A B S T R A C T
As the rapid development of Genetically Modified crops, Chinese government has been increasing its efforts in GM crop biosafety management. However, the rapid expansion of Bacillus thuringiensis $(\mathrm{Bt})$ cotton varieties and less regulated seed industry also resulted in a large amount of Bt cotton varieties that bypassed China's biosafety regulations. This study shows that the Bt cotton varieties without biosafety certificates $(\mathrm{BC})$ have been widely used by farmers in practice. Econometric analysis further shows that the Bt cotton varieties with $\mathrm{BC}$ outperform the varieties without $\mathrm{BC}$ in terms of pesticide use. The paper concludes with policy implications.
\end{abstract}

(c) 2015 Elsevier Inc. All rights reserved.

\section{Introduction}

The multiple benefits and success of Bacillus thuringiensis (Bt) technology have been well documented in major countries where Bt crops were planted (Hurley, Secchi, Babcock, \& Hellmich, 2001; Pray, Ma, Huang, \& Qiao, 2001; Qaim, 2003). For example, the empirical studies in China showed that Bt cotton adoption has derived significant and multiple benefits, including increasing yields and falling production cost from the reduction of pesticide applications (for example, Huang, Hu, Pray, Qiao and Rozelle, 2003; Huang, Hu, Rozelle, Qiao, \& Pray, 2002). Such gains also have been translated into economic, human health and environmental benefits (Hossain et al., 2004; Kouser \& Qaim, 2013). In developing countries, Genetically Modified (GM) crops also have contributed to poverty reduction, improvements of nutrition and food security (Qaim, 2010). In addition, empirical studies showed that the benefits that GM crops had generated are stable in a longer-term (Kathage \& Qaim, 2012; Smale et al., 2009).

However, along with the above positive evidences, significant opposition to GM technology has aroused. The negative attitudes often seem to dominate the public debate on the advantage and disadvantage of GM technology, especially in recent years (Cleveland \& Soleri, 2005; Kathage \& Qaim, 2012). Those against GM technology worry that the widespread of GM crops would damage environments and human health and have adverse social implications (Friends of the Earth, 2008; Sharma, 2004).

\footnotetext{
* Corresponding authors.

E-mail addresses: jkhuang.ccap@igsnrr.ac.cn (J. Huang), qiaofangbin@cufe.edu.cn (F. Qiao).
} 
Due to the rising public reservations and the existence of externalities, the GM technology is heavily regulated (Qaim, 2009). For a novel technology, regulators are extremely cautious to make sure that the food produced under this novel technology is safe for human and environments. At the same time, the rising opposition also gives the government high pressure to regulate GM technology strictly. As a result, GM seed varieties are heavily regulated in most countries where GM crops were planted (Qaim, 2009). For example, according to regulations released in China, no GM crop varieties without biosafety certificate (BC) can be sold in the market (Huang \& Wang, 2002).

One of the consequences from strict biosafety regulation is the widespread of unapproved varieties in practice. Well-established and implemented regulations can strike low quality seeds (for example those without biosafety certificate) out of market and benefit both the farmers and consumers. However, no benefit comes without cost (Smale et al., 2009). Strict regulation and high cost associated with regulatory process have prevented some seed companies, especially those small seed companies, from applying for official certificates (Pray, Huang, et al., 2006). On the other hand, weak intellectual property rights (IPR) makes getting genetic materials easy and less expensive in developing countries. Consequently, even small seed companies can produce their own varieties. Moreover, the existence of tens of thousands of seed companies/dealers makes implementing seed laws and regulations and monitoring violations a hard work (Huang, Chen, Mi, Hu, \& Osir, 2009). All these factors, working together, make unapproved varieties quite common in practice (Herring, 2007).

The existence of the unapproved varieties raised several questions. For example, how serious are unapproved varieties (or the varieties without $\mathrm{BC}$ ) in farm field? More importantly, how is the efficacy of these Bt cotton varieties without BC in controlling insects in field production? Do farmers consider the Bt cotton varieties without BC different from those varieties with BC? In other words, do farmers spray more pesticide in fields where varieties without BC are planted than in the fields where varieties with BC are planted?

The overall goal of this study is to empirically answer the above questions. To meet this overall goal, we have three specific objectives. First, we provide a profile of China's biosafety regulations and seed market. Second, using survey data collected in Northern China Plain, we document the share of cotton varieties without BC and descriptively chart the way that farmers appear to spray more in plots planted with varieties without BC than those planted with varieties with BC. Finally, we empirically estimate whether BC, all other things equal, are associated with farmer' pesticide use by estimating multivariate regression econometric models.

The rest of the paper is organized as follows. Section 2 briefly provides background information on China's biosafety regulations and the existence of varieties without BC in China's cotton seed market. The data collected from farm household surveys are described in Section 3. Then we empirically examine the efficiency of these two types of Bt cotton varieties (i.e., varieties with BC and varieties without BC) through their performance in farmers' fields. Discussion and policy implications from this study are provided in the final section.

\section{China's biosafety regulations and varieties without $B C$}

As the rapid development of GM industry, the Chinese government has paid great attention to the biosafety management of GM crops (Huang \& Wang, 2002). In early 1993, the Chinese State Science and Technology Commission (SSTC) released the first set of biosafety regulations, the "Safety Administration and Regulation on Genetic Engineering" (Chinese State Science and Technology Commission, 1993). Following the SSTC's regulations, the Ministry of Agriculture (MOA) issued the "Implementation Measures for Agricultural Biological Engineering" in 1996 (MOA, 2005). Since then, the policy and regulatory on biosafety have become more stringent. In May 2001 the State Council decreed a new set of policy guidelines, the "Regulations on the Safety Administration of Agricultural Genetically Modified Organisms (GMOs)" to replace the early regulations issued by SSTC in 1993. MOA also announced three new implementation regulations to replace their earlier rules. The new framework, which took effect in March 2002, greatly expanded the scope of regulation to include more detailed rules on biosafety management, trade and labeling of GM food products. These laws and regulations consisted of general principles, safety categories, risk evaluation, application and approval, safety control measures, and legal responsibilities. ${ }^{1}$

In addition, special institutions in charge of the formulation and implementation of biosafety regulations on agricultural GMOs and their commercialization were established. The National GMOs Biosafety Committee was established in 1997 when the first GM crop, Bt cotton, was commercialized. As a major player in the process of biosafety management, this committee evaluates all biosafety assessment applications related to experimental research, field trials, environmental release, pre-production and commercialization of agricultural GMOs. It provides recommendations (approval or disapproval) to the Office of Agricultural Genetic Engineering Biosafety Administration (OGEBA). The OGEBA is responsible for the final decision on whether to approve an application. If the commercialization of a GM crop is approved, the applicant will receive a $\mathrm{BC}$ for commercialization.

Biosafety regulation institutions have been also established at agricultural bureaus at local levels (i.e., province and county). These local institutions are mainly in charge of the monitoring and reporting GM crop production and marketing at their own region after approval of GM crop commercialization by MOA. However, based on our field interviews, capacity of most local biosafety regulation institutions is weak. ${ }^{2}$ Given largely unregulated seed markets in China, which is further discussed below, the actual role of monitoring GM crop production and marketing is very limited.

\footnotetext{
1 The detailed discussions on China's biosafety regulations, tests, process and application have been published in the literature (for example, Huang \& Wang, 2002; Pray, Ramaswami, et al. 2006).

2 Monitoring and management of agricultural GMOs are side works of local agriculture bureau. And because there are tens of thousand seed companies/dealers, it is reasonable to assume the cost of violations of agricultural laws and regulations is quite low as the probability of being caught and punished is very low (Huang \& Wang, 2002; Pray, Ramaswami, et al., 2006).
} 
Despite the resources and time invested in promulgating regulations and setting up new institutions for biosafety management, Bt cotton varieties without BC are found widely in seed market. In fact, the varieties without BC can be roughly classified into two groups. The first group of varieties without BC is renamed from varieties with BC. In other words, they are the unapproved varieties with approved Bt gene. The second group of varieties without BC is those varieties that really bypassed biosafety regulations (or unapproved varieties without approved Bt gene).

There are at least two reasons behind the existence of the unapproved varieties with approved Bt gene. First, both the seed producers and dealers have the incentives to rename varieties with BC. To do so, the seed producers can avoid royalties or license fees. Similarly the seed dealers, particularly small dealers, would also like to create a new name for existing Bt cotton varieties to avoid paying license fees, and/or the responsibility and tort liability (Huang et al., 2009). ${ }^{3}$

The second reason that seed producers and dealers would like to rename cotton variety is that they found that farmers prefer to buy new varieties than those sold in previous years (Huang et al., 2009). Hence they have incentives to rename their products. In other words, renaming their products would differentiate their products from others and make their products more attractive to farmers.

On the other hand, there are also some varieties that actually bypass biosafety regulations for a few reasons. First, the high regulation cost and long approval process of biosafety regulation give incentive to seed companies, particular small seed companies, to bypass the government biosafety regulation system. ${ }^{4}$ Previous studies showed that it took great efforts, direct and indirect transaction costs, to get a new GM variety approved in developing countries (for example, Pray, Huang, et al., 2006; Pray, Prajakta, \& Ramaswami, 2005). Similarly, in China, according to the biosafety regulations, to complete biosafety assessment procedures from experimental research to field trials, environmental release, pre-production and commercialization, a successful GM crop technology could take more than ten years (Huang et al., 2009). And the protection of property right in China, even though has been improved significantly in recent years, is still weak (Fang, Cheng, Xu, Xu, \& Fan, 2001; Hu et al., 2009). Hence, seed companies/dealers do not have to apply BC to sell seed. Consequently, seed companies have no incentive to apply for BC for their new varieties.

Second, the approval of an application at provincial and prefecture levels is not so strict, which makes it possible for some varieties to bypass the regulations. As in the national level, provincial and prefecture levels also have their own committees. Similar to conventional varieties, GM crop varieties also typically undergo three years of multi-location regional varietal trails and registration. Based on this regional varietal trial, provincial seed management committee composed of officials, local agricultural scientists and breeders select promising seed varieties for release at the province or regional level. As the seed market is under-regulated, there are always some seed companies, most are small seed companies, that bypass the regional varietal trails and registration. Of course this is not only limited to GM but also non-GM varieties.

The last but not least, China's seed market is highly unregulated and extremely competitive. After the seed market reforms initiated in the mid-1990s, China's state cotton seed system has been decentralized and commercialized. By the middle 2000s, it is believed that there are several thousands of seed companies in China's seed market (Hu et al., 2009). The market is very competitive, unregulated, and dominated by independent and small companies and seed dealers (Huang et al., 2009). The different markets, ranging from the county capital to local townships and villages, often sell different varieties, and the number of varieties in the market is increasing, which makes the monitoring of varieties and quality of seed costly. In addition, monitoring the implementation of Biosafety regulation is just a side work of local agricultural bureaus, and their capacity is weak. Under this situation, it is not difficult to understand that many private small seed companies and some local public research institutes (usually at prefecture level) often backcross commercially available seeds to generate their own Bt cotton varieties and directly sell them in the local market without approval (Huang et al., 2009).

\section{Data, sampling method and Bt cotton varieties}

The data used in this study are collected by the Center for Chinese Agricultural Policy (CCAP) of Chinese Academy of Sciences (CAS) in 2006 and 2007. Early in 1999, CCAP conducted the first around survey to understand the economic impacts of Bt cotton in the Yellow River valley, the largest cotton production region in China (60\% of China's cotton area in 2006). By 2007, the other five rounds of surveys (2000, 2001, 2004, 2006 and 2007) were conducted. In successive surveys, the sample size is increased as Bt cotton expanded from the Yellow River valley to Yangtze River Valley, the second largest cotton production region. The database in early years has been used to assess the effects (i.e., the economic benefit) of Bt cotton relative to conventional cotton varieties in China (e.g., Huang et al., 2003, 2002; Pray et al., 2002, 2001).

The 2006 year survey covers 320 households in 16 villages (20 households in each village) from eight counties of four provinces. These four provinces are Shandong, Hebei, Henan, and Anhui which are the second, third, fourth, and sixth largest cotton production provinces in China (National Bureau of Statistics of China 2008). ${ }^{5}$ In each province, two counties were randomly selected from the list of major cotton production counties. Following the similar procedure, we randomly selected two villages where cotton was a major crop in each county. Finally in each village, 20 cotton households were randomly sampled.

\footnotetext{
3 Huang et al. (2009) is based on a field survey in 2007. The field survey was conducted in six county capitals, eight township headquarters, and 12 villages in the NCP. In total, the survey covered 176 seed companies and/or dealers.

${ }^{4}$ As there are tens of thousands of seed companies/dealers, China's seed market is pretty competitive. On the other hand, the implementation and monitoring of seed laws and regulations are weak. Hence, even if a seed company/dealer violates the laws/regulations, the probability of getting caught and the cost of being punished for circumventing the regulatory system are almost ignorable.

${ }^{5}$ Xinjiang Uyghur Autonomous Region is the largest cotton production region in China. However, because of the hot and dry climate, the cotton bollworm is not a serious problem in Xinjiang.
} 
The 2007 year survey includes 6 counties in 3 provinces in the NCP. While Anhui Province was excluded due to lack of funding, it should not let to sample bias as the farmers in Anhui and the other three sample provinces in the NCP are very similar. In total 240 households in 12 villages were surveyed in 2007.

We selected 2006 and 2007 survey data for this study for a couple of reasons. First, the presence of the Bt cotton varieties without $\mathrm{BC}$ is not common before 2004. The number of Bt cotton varieties identified by names has been significantly increased mainly after the mid-2000s. Second, in 2006 and 2007 surveys, we paid much more attention to names and sources of Bt cotton varieties adopted by farmers and their attitudes on different sources of Bt cotton varieties.

The household survey includes a number of different blocks. First, there are sections that cover the basic information of the household, such as demographic information of each family member (gender, age, education, marital status, etc.), farm size and household assets. Another section is used to elicit information about cotton output and inputs, such as yield, seed, soil quality, chemical fertilizer and pesticide use. To accurately measure the relationship between inputs and output, all the input and output data were collected by plot.

To fully understand the difference of pesticide use between varieties with and without BC, the household survey includes a section about the source of the Bt cotton seed planted in each plot. For each variety, we recorded the name, source of the seed and the price of the seed. For those varieties that only have local names, we consulted local agricultural extension technicians to get their formal names and characteristics. Finally, for all cotton varieties planted by farmers, we checked whether they had been approved by the OAGEBA. If they were in the list of approved Bt cotton varieties, we labeled them as the Bt cotton varieties with BC, otherwise they were labeled as varieties without BC.

It is worth to note that some Bt cotton varieties without BC could be varieties with BC actually, as discussed above. We admit that there exists the mixture of some varieties actually with BC in the group of varieties without BC, but we consider that the data are still good enough to provide the empirical answers to the research questions raised earlier. For example, while we are not able to separate the varieties that actually bypassed biosafety regulation system from the current whole group of varieties labeled with "without BC", if there is no statistically significant difference in the pesticide use between the two groups of varieties, we would not be able to reject the hypothesis of the equal efficacy of them. That is the research question to be examined in this study. In fact, we are more interested in farmers' reactions to these two types of Bt cotton varieties (with and without BC). If we could not find out whether a variety actually has $\mathrm{BC}$ but is included in the group of varieties without $\mathrm{BC}$ because of change in its name, we believe that farmers could find out this neither.

Our survey data show that a considerable proportion of farmers planted Bt cotton varieties without BC in practice (Table 1). On average, share of plots planted with varieties with BC is $57.4 \%$, which is similar to the share of areas planted with varieties with BC (56.6\%). In other words, near half of the cotton field is planted with Bt cotton varieties without BC. In addition, we find that the share of plots planted with the varieties with BC is 57.3\% in 2007, which is very similar to that in 2006 (57.5\%). Hence, even though more cotton varieties have been approved in each year, especially in recent years, varieties without BC are still widely planted in China's cotton field production.

However, the proportion of the varieties with BC varies substantially across provinces. In 2006, share of plots planted with varieties with BC is only 17.2\% in Henan Province, while this number is as high as $81.0 \%$ in Shandong Province (the second column, rows 3 and 4 , Table 1). Similarly, share of plots planted with varieties with BC is $34.8 \%$ in Henan Province, while it is $85.7 \%$ in Shandong Province in 2007 (rows 8 and 9). Similar results can be found if we recalculate the share of the varieties with BC in terms of areas (last column, Table 1).

\section{Results}

\subsection{Descriptive analysis}

Table 2 shows that cotton farmers who planted the varieties without BC sprayed more pesticides than those who planted the varieties with $\mathrm{BC}$. As shown in the second column, average pesticide use in plots planted with the varieties without $\mathrm{BC}$ is $26.5 \mathrm{~kg} / \mathrm{ha}$, while it is $19.8 \mathrm{~kg} / \mathrm{ha}$ in plots planted with the varieties with BC (the first two rows). In addition, we find that the varieties with BC outperform the varieties without BC in every county studied (the second column, Table 2).

On the other hand, the yield difference between the varieties with and without BC is not significant. As shown in the third column of Table 2, average yield of the varieties without BC is $3173.5 \mathrm{~kg} / \mathrm{ha}$, which is almost the same as that of the varieties with BC (3155.4 $\mathrm{kg} / \mathrm{ha}$ ).

Table 1

Varieties with and without biosafety certificates (BC) in Bt cotton production in 2006 and 2007.Source: authors' survey.

\begin{tabular}{llll}
\hline & Total number of plots surveyed & Share of plots planted with varieties with BC (\%) & Share of areas planted with varieties with BC (\%) \\
\hline Total & 1498 & 57.4 & 56.6 \\
Sub-total in 2006 & 931 & 57.5 & 58.3 \\
$\quad$ Henan & 134 & 17.2 & 15.1 \\
Shandong & 290 & 81.0 & 80.0 \\
Hebei & 235 & 63.4 & 63.6 \\
Anhui & 272 & 47.1 & 52.2 \\
Sub-total in 2007 & 567 & 57.3 & 53.9 \\
Henan & 132 & 34.8 & 31.0 \\
Shandong & 237 & 85.7 & 84.0 \\
Hebei & 198 & 38.4 & 33.7 \\
\hline
\end{tabular}


Table 2

Pesticide use, cotton yield and varieties with and without biosafety certificates (BC) in 2006-2007.Source: authors' survey.

\begin{tabular}{|c|c|c|c|}
\hline & Number of plots & Pesticide use (kg/ha) & Cotton yield $(\mathrm{kg} / \mathrm{ha})$ \\
\hline \multicolumn{4}{|l|}{ All Bt plots } \\
\hline Without BC & 638 & 26.5 & 3173.5 \\
\hline With BC & 1105 & 19.8 & 3155.4 \\
\hline T-values & & $(8.38)^{* * *}$ & $(0.38)$ \\
\hline \multicolumn{4}{|l|}{ Taikang, Henan } \\
\hline Without BC & 57 & 18.0 & 1960.0 \\
\hline With BC & 88 & 16.3 & 1829.8 \\
\hline T-values & & $(1.09)$ & $(1.57)$ \\
\hline \multicolumn{4}{|l|}{ Fugou, Henan } \\
\hline Without BC & 140 & 19.8 & 2166.8 \\
\hline With BC & 62 & 19.0 & 1584.0 \\
\hline T-values & & $(0.40)$ & $(5.65)^{* * *}$ \\
\hline \multicolumn{4}{|c|}{ Liangshan, Shandong } \\
\hline Without BC & 42 & 10.6 & 2812.0 \\
\hline With BC & 265 & 10.3 & 2878.9 \\
\hline T-values & & $(0.29)$ & $(0.74)$ \\
\hline \multicolumn{4}{|c|}{ Xiajin, Shandong } \\
\hline Without BC & 47 & 28.6 & 3756.6 \\
\hline With BC & 257 & 21.6 & 3667.8 \\
\hline T-values & & $(2.89)^{* * *}$ & $(1.01)$ \\
\hline \multicolumn{4}{|c|}{ Shenzhou, Hebei } \\
\hline Without BC & 80 & 20.3 & 3035.3 \\
\hline With BC & 181 & 17.4 & 2866.5 \\
\hline T-values & & $(2.34)^{* *}$ & (1.89) \\
\hline \multicolumn{4}{|l|}{ Xinji, Hebei } \\
\hline Without BC & 128 & 38.8 & 3644.7 \\
\hline With BC & 124 & 37.5 & 3659.3 \\
\hline T-values & & $(0.66)$ & $(0.26)$ \\
\hline \multicolumn{4}{|l|}{ Dongzhi, Anhui } \\
\hline Without BC & 62 & 29.8 & 4034.4 \\
\hline With BC & 68 & 25.3 & 4361.1 \\
\hline T-values & & $(1.23)$ & $(2.70)^{* * *}$ \\
\hline \multicolumn{4}{|c|}{ Wangjiang, Anhui } \\
\hline Without BC & 82 & 35.3 & 4335.1 \\
\hline With BC & 60 & 24.1 & 4212.3 \\
\hline T-values & & $(3.07)^{\text {*** }}$ & $(1.27)$ \\
\hline
\end{tabular}

*** Denotes significance at $1 \%$.

** Denotes significance at $5 \%$

* Denotes significance at $10 \%$.

In addition, the yield difference is inconsistent across regions. For example, in Taikang, Fugou, Xiajin, Shenzhou and Wangjiang counties, the varieties without BC outperform the varieties with BC. However, in Liangshan, Xinji and Dongzhi counties, the result is opposite.

Based on the descriptive analysis, it seems that there are relationships on types of varieties (i.e., BC and non-BC) and pesticide use, but none on cotton yield. Farmers might consider the varieties without $\mathrm{BC}$ as inferior to those with $\mathrm{BC}$. As a result, farmers who planted varieties without $\mathrm{BC}$ usually would like to spray more pesticides. However, pesticide overuse is a common phenomenon even in $\mathrm{Bt}$ cotton fields (Huang, Hu, Pray, Qiao, \& Rozelle, 2003; Pemsl, Waibel, \& Gutierrez, 2005; Yang, Iles, Yan, \& Jolliffe, 2005). Hence, more use of pesticide in plots planted with varieties without BC does not contribute to the crop yield as we observed in Table 2.

However, the descriptive analysis only shows the unconditional relationship between pesticide use and the types of varieties adopted by farmers. It is possible that there are other factors that are confounding our results. Therefore, in the next sub-section we are going to set up and run multivariate regression models to formally test the conditional relationship between pesticide use and the varieties with and without $\mathrm{BC}$.

\subsection{Multivariate regression analysis}

To better understand the second research question on farmers' responses to the two types of Bt cotton varieties (i.e., with BC and without BC) in terms of pesticide use, we adopt a multivariate function approach based on 2006-2007 survey data. Our ultimate objective is to estimate the net difference of these two types of varieties on pesticide use, especially the pesticide used to control cotton bollworm. To do so, we need to hold the effect of many other factors, such as characteristics of household and plot, constant. To achieve this objective, we set up the following equation: 
Table 3

Basic statistics of major variables.Source: authors' survey.

\begin{tabular}{|c|c|c|c|}
\hline & $\begin{array}{l}\text { All } \\
\text { varieties }\end{array}$ & $\begin{array}{l}\text { Varieties with biosafety certificates } \\
(\mathrm{BC})\end{array}$ & $\begin{array}{l}\text { Varieties without biosafety certificates } \\
\text { (BC) }\end{array}$ \\
\hline Total pesticide use in quantity (kg/ha) & 22.3 & 19.8 & 26.5 \\
\hline Pesticide use against bollworm (kg/ha) & 8.6 & 7.5 & 10.5 \\
\hline Total pesticide cost (yuan/ha) & 638.3 & 570.4 & 755.9 \\
\hline Pesticide cost for controlling bollworm (yuan/ha) & 222.2 & 198.0 & 264.3 \\
\hline Pesticide price (yuan $/ \mathrm{kg}$ ) & 30.5 & 30.6 & 30.3 \\
\hline High quality soil ( $1=$ high quality, $0=$ otherwise $)$ & 0.4 & 0.4 & 0.3 \\
\hline Middle quality soil ( $1=$ middle quality, $0=$ otherwise $)$ & 0.5 & 0.5 & 0.5 \\
\hline Plot size (ha) & 0.2 & 0.2 & 0.2 \\
\hline Age of household head (year) & 49.3 & 49.4 & 49.2 \\
\hline Education of household head (year) & 7.4 & 7.4 & 7.5 \\
\hline Family farm size (ha) & 0.7 & 0.7 & 0.8 \\
\hline
\end{tabular}

where, the dependent variable, pesticide use is defined in terms of quantity (measured as kilograms per hectare) and cost (yuan per hectare), alternatively. In this study, we not only estimate total amount of pesticide applied for all pests, but also the amount of pesticide sprayed to control the cotton bollworm only. Variety_ $B C$ is a dummy variable, which equals to 1 if the cotton variety belongs to the group of varieties with $\mathrm{BC}$, and 0 otherwise.

The Pesticide price variable is constructed as a unit value of pesticides applied by the farmer. Characteristics of household include the age and education of the household head, and family farm size. Characteristics of plot include plot size and two dummy variables to measure soil quality: high quality soil dummy $(1=$ high quality, $0=$ otherwise $)$, and middle quality soil dummy $(1=$ middle quality, $0=$ otherwise). Finally, we also include 2007 year dummy and village dummies to control for the changes in overall time and variations among villages. Basic statistics of these variables are shown in Table 3. As shown in Table 3, characteristics of varieties without BC and that of varieties with $\mathrm{BC}$ are similar except for pesticide use (rows 1-4).

The estimation results are shown in Table $4 .{ }^{6}$ In general, our econometric estimation appears to perform well in all the specifications. In addition, the signs of most of the coefficients estimated are also as expected. For example, the negative signs of Pesticide price variable in the pesticide quantity equations indicate that higher pesticide price dampen the amount of pesticide that farmers apply. In contrast, the positive coefficients on the Pesticide price variable in the pesticide cost equations mean that farmers pay more as pesticide price rises. For another example, education of household head has a significantly negative impact on pesticide use, which shows that more educated farmers use less pesticide. Finally, plot size has negative sign in all the equations indicating that there are scale economies in the use of pesticide.

More importantly, our analysis allows us to estimate the impact of banning the varieties without BC (e.g., through enforcing biosafety regulations and seed market regulations) in the market on pesticide use. This impact is reflected in the estimated coefficient of variety with BC. As shown in Table 4, the estimated coefficients of this variable are negative and statistically significant in all the models, which indicates that enforcing biosafety and seed market regulations could decrease both the pesticide use in quantity and expenditure (row 1). If farmers plant varieties with $\mathrm{BC}$, their pesticide use is $1.85 \mathrm{~kg} / \mathrm{ha}(8.30 \%)$ less than those who plant varieties without BC. For pesticide use against cotton bollworm, the reduction could be as high as $16.16 \%$ (1.39 $\mathrm{kg} / \mathrm{ha})$. In other words, if the varieties without $\mathrm{BC}$ could be effectively kept out of the seed market, the amount of pesticide that farmers spray would have been much less.

The same was true in the case of pesticide cost equations (the third and fourth columns, Table 4). The estimation results show that the pesticide cost of the plots planted with varieties with $\mathrm{BC}$ is 53.48 yuan/ha (or 8.38\%), less than that planted with the varieties without $\mathrm{BC}$ (row 1). Similarly, the estimation results show that the pesticide cost against cotton bollworm in plots planted with varieties with $B C$ is 30.63 yuan/ha (or $13.78 \%$ ) less than that planted with varieties without BC.

The estimated results also allow us to calculate the possible effect of enforcing bio-safety regulations in China. As shown in Table 1 , legally speaking, near half of the varieties used in the field is varieties without BC. If the bio-safety regulations would be strictly enforced and varieties without BC were banned, according to our analysis and the area of Bt cotton in China (James, 2007), total pesticide use would decrease by $0.79 \mathrm{~kg}((100 \%-57.4 \%) *(-1.85))$ per ha, or 3.00 million $\mathrm{kg}$ in China $(0.79 \mathrm{~kg} / \mathrm{ha} * 3.8 \mathrm{million}$ ha). For pesticide used to control cotton bollworm, the reduction would be $0.59 \mathrm{~kg}((100 \%-57.4 \%) *(-1.39))$ per ha, or $2.25 \mathrm{million} \mathrm{kg}$ in China in 2007. Using the similar method, we can calculate the pesticide cost saving on the total pesticide use (86.56 million yuan) and pesticide use against cotton bollworm only ( 49.59 million yuan). In other words, this study shows that strengthening the supervision of bio-safety approval management and banning the varieties without $\mathrm{BC}$ will enable farmers to gain more from the adoption of GM technology.

\footnotetext{
${ }^{6}$ To consider the impact of potential sample selection bias, we re-estimated our models under two scenarios: 1) estimate the models using household as clusters; and 2 ) estimate the models using households who planted both varieties with BC and varieties without BC. The estimation results under these two scenarios are very similar and consistent to that discussed in the paper.
} 
Table 4

Regression results on pesticide use in Bt cotton production.Source: authors' survey.

\begin{tabular}{|c|c|c|c|c|}
\hline & \multicolumn{2}{|c|}{ Pesticide quantity (kg/ha) } & \multicolumn{2}{|c|}{ Pesticide cost (yuan/ha) } \\
\hline & Total & Against bollworm & Total & Against bollworm \\
\hline Variety with $\mathrm{BC}(1=$ yes; $0=$ no $)$ & $\begin{array}{l}-1.85 \\
(2.54)^{* *}\end{array}$ & $\begin{array}{l}-1.39 \\
(3.56)^{* * *}\end{array}$ & $\begin{array}{l}-53.48 \\
(2.67)^{* * *}\end{array}$ & $\begin{array}{l}-30.63 \\
(2.90)^{* * *}\end{array}$ \\
\hline Pesticide price (yuan/kg) & $\begin{array}{l}-0.37 \\
(12.45)^{* * *}\end{array}$ & $\begin{array}{l}-0.10 \\
(6.24)^{\text {*** }}\end{array}$ & $\begin{array}{l}2.39 \\
(2.90)^{* * *}\end{array}$ & $\begin{array}{l}0.70 \\
(1.61)\end{array}$ \\
\hline Age of household head (year) & $\begin{array}{l}0.01 \\
(0.17)^{*}\end{array}$ & $\begin{array}{l}-0.01 \\
(0.54)\end{array}$ & $\begin{array}{l}0.34 \\
(0.30)\end{array}$ & $\begin{array}{l}-0.23 \\
(0.39)\end{array}$ \\
\hline Education of household head (years) & $\begin{array}{l}-0.26 \\
(2.21)^{* *}\end{array}$ & $\begin{array}{l}-0.14 \\
(2.20)^{* *}\end{array}$ & $\begin{array}{l}-8.99 \\
(2.78)^{* * *}\end{array}$ & $\begin{array}{l}-4.04 \\
(2.36)^{\text {** }}\end{array}$ \\
\hline Family farm size (ha) & $\begin{array}{l}-0.29 \\
(0.25)\end{array}$ & $\begin{array}{l}-0.22 \\
(0.35)\end{array}$ & $\begin{array}{l}14.61 \\
(0.45)\end{array}$ & $\begin{array}{l}-11.72 \\
(0.69)\end{array}$ \\
\hline Plot size (ha) & $\begin{array}{l}-6.64 \\
(2.83)^{* * *}\end{array}$ & $\begin{array}{l}-0.96 \\
(0.76)\end{array}$ & $\begin{array}{l}-158.92 \\
(2.47)^{* *}\end{array}$ & $\begin{array}{l}-35.88 \\
(1.05)\end{array}$ \\
\hline High quality soil dummy ( $1=$ yes; $0=$ no $)$ & $\begin{array}{l}-1.37 \\
(1.33)\end{array}$ & $\begin{array}{l}-0.46 \\
(0.84)\end{array}$ & $\begin{array}{l}-70.68 \\
(2.49)^{* *}\end{array}$ & $\begin{array}{l}-20.98 \\
(1.40)\end{array}$ \\
\hline Middle quality soil dummy ( $1=$ yes; $0=$ no $)$ & $\begin{array}{l}-0.68 \\
(0.68)\end{array}$ & $\begin{array}{l}0.62 \\
(1.15)\end{array}$ & $\begin{array}{l}-40.86 \\
(1.49)\end{array}$ & $\begin{array}{l}6.20 \\
(0.43)\end{array}$ \\
\hline 2007 year dummy & $\begin{array}{l}-4.02 \\
(5.62)^{* * *}\end{array}$ & $\begin{array}{l}-0.88 \\
(2.28)^{* *}\end{array}$ & $\begin{array}{l}-95.61 \\
(4.86)^{* * *}\end{array}$ & $\begin{array}{l}-28.96 \\
(2.78)^{* * *}\end{array}$ \\
\hline 15 village dummies & \multicolumn{4}{|c|}{ Estimated but not reported } \\
\hline Constant & $\begin{array}{l}35.35 \\
(11.09)^{\text {*** }}\end{array}$ & $\begin{array}{l}9.08 \\
(5.31)^{* * *}\end{array}$ & $\begin{array}{l}603.74 \\
(6.89)^{* * *}\end{array}$ & $\begin{array}{l}156.08 \\
(3.37)^{* * *}\end{array}$ \\
\hline Observations & 1743 & 1743 & 1743 & 1743 \\
\hline $\mathrm{R}^{2}$ & 0.38 & 0.46 & 0.38 & 0.41 \\
\hline
\end{tabular}

Notes: the figures in the parentheses are standard errors of estimates.

BC stands for biosafety certificates.

*** Denotes significance at $1 \%$.

** Denotes significance at $5 \%$.

* Denotes significance at $10 \%$.

\section{Discussions}

In this study, we estimate the differences of varieties with BC and varieties without BC through examining their pesticide use in fields. Consistent with what we had expected, this study shows that farmers spray less pesticide in plots planted with varieties with BC than those planted with varieties without BC. In other words, this study shows that varieties with BC outperform varieties without BC in terms of pesticide use by farmers.

However, why did farmers spray less pesticide in plots planted with varieties with $B C$ ? Is the expression of Bt toxin of varieties with $\mathrm{BC}$ higher than that of varieties without BC? To answer this question, we also tested the expression levels of Bt toxin of these two types of varieties using laboratory test data collected in 2007. The laboratory test data were collected and analyzed as follows. First, in each cotton plot, we collected cotton leaves three times in June, July and August. Each time, we selected five cotton plants (four in corners and one in the center) in each plot. And then four pieces of leaves from each plant were picked up. Second, after being collected, all leaves were immediately put into a refrigerator filled with ice and then were shipped to the Institute of Plant Protection (IPP) of Chinese Academy of Agricultural Sciences in Beijing. Finally, IPP conducted the laboratory analysis of the expression of Bt protein toxin for each plot in these periods (June, July and August).

Surprisingly, the varieties with BC did not outperform the varieties without BC in terms of expression of Bt toxin. The expression level of Bt toxin determines the efficiency of Bt cotton in controlling the pest infestation. Hence, high dose is one of the most important criteria of the approval of new Bt crop varieties. However, our laboratory results showed that the average Bt toxin expression level of cotton varieties with BC was $961 \mathrm{ng} / \mathrm{g}$ in June-August in 2007, which was even slightly lower than that (1044 ng/g) for the Bt cotton varieties without $\mathrm{BC}$ over the same period though the difference is not statistically significant.

There are at least two reasons behind this finding. First, Huang et al. (2009) found that some Bt cotton varieties with BC were renamed and sold in a local market. In this case, although a variety by name belongs to the one without BC, actually its Bt toxin expression level should be indifferent from the varieties with BC. Second, to avoid long process of biosafety regulatory process and high regulation cost, companies, particular small companies, have incentives to bypass the biosafety regulation and directly sell farmers the Bt cotton varieties that indeed also have high level of Bt toxin expression.

Then why did farmers spray less pesticide in plots planted with varieties with BC, even though these varieties did not outperform varieties without BC in terms of expression of Bt toxin? While we are not able to provide a direct answer to this question, during the household survey, we also conducted a seed market survey at village, township and county capital and found that varieties with BC were usually from big companies and sold in large seed stores at a higher price, while varieties without BC usually were from small companies and sold in small seed stores at a cheaper price. The previous study also had similar observation (Huang et al., 2009). They found that the renamed Bt cotton varieties often came from small companies and were largely sold in small shops at township 
or village. The varieties without BC and with cheaper prices may give farmers an impression that they were inferior to varieties with $\mathrm{BC}$. And this perception might be the reason, or one of the reasons, that they spray more pesticide in plots planted with varieties without BC.

The findings of this study help us identify several areas that deserve the attention of policy makers. First, Chinese government may need to reconsider its current case-by-case (e.g., by variety and by region) biosafety regulation policy. In many major GM crop producing countries, including US, GM varieties approved for commercialization are based on GM event. As long as a GM event is approved, all varieties with the same GM event are also approved with BC, which significantly reduce the biosafety regulation and application costs for GM varieties and also can accelerate adoption of new GM varieties. Reduction of the regulation and application cost will encourage more companies, especially those small seed companies, to apply for BC (Pray et al., 2005). Then, the supply chain of the varieties without BC will be disrupted and those varieties without BC will not be available in the seed market (Lalitha, Pray, \& Ramaswami, 2008).

Second, the findings of this study also have policy implication on agricultural technology extension. In many countries, farmers often lack knowledge on appropriate use of new technologies (Matteson, Gallagher, \& Kenmore, 1993; Pontius, Dilts, \& Bartlett, 2002). Empirical studies in China's cotton production showed that it is very common for farmers to overuse pesticides due to farmers' lacking knowledge on pest management (Chen, Huang, Rozelle, \& Qiao, 2012; Yang et al., 2005). As shown in this study, if farmers know that the expression of Bt toxin of varieties without BC is not inferior to that of varieties with BC, they would have sprayed less pesticide in plots planted with varieties without BC. Even though more pesticide use did not lead to yield loss, it increases production cost and has a negative impact on environment and human health (Hossain et al., 2004; Huang et al., 2003; Qiao, Huang, Zhang, \& Rozelle, 2012).

Finally, more efforts may be needed to strictly monitor and prohibit the varieties without BC selling in market. Even though there are agencies in central and local levels to enforce the biosafety regulations, the implementation of these regulations is facing challenges. There are thousands of seed companies and millions of small seed dealers in the market. China's current effort is to consolidate seed market by supporting the large seed companies and raising seed market entry condition. But more investments in on-the-ground enforcement capacity for regulations are also necessary.

\section{Acknowledgments}

The authors are grateful to the staff of the Center for Chinese Agricultural Policy who worked so hard in collecting data. We would like to thank Carl Pray, Scott Rozelle, Robert Tripp, and Ellie Osir for their comments. The authors acknowledge the financial supports of this study from the GMO Program of the Ministry of Agriculture (2011ZX08015-002A), International Development Research Center (IDRC, 103783-001; 106160-002)), and National Natural Science Foundation of China (71273290).

\section{References}

Chen, R., Huang, J., Rozelle, S., \& Qiao, F. (2012). Farmers' knowledge and pesticide use in Bt cotton production in China. Working Paper, Center for Chinese Agricultural Policy, Chinese Academy of Sciences, May, 2012.

Chinese State Science and Technology Commission (1993). Biosafety Administration Regulations on Genetic Engineering. Available at: http://english.biosafety.gov.cn/ swaqxxjhs/flfg/200401/t20040116_88132.htm

Cleveland, D., \& Soleri, D. (2005). Debate over a GM rice trial in China. Science, 310, 231-232.

Fang, X., Cheng, D., Xu, J., Xu, R., \& Fan, T. (2001). Commercial implementation of intellectual property rights of Chinese transgenic insect resistant cotton with Bt gene and $\mathrm{Bt}+\mathrm{CpTI}$ genes. Journal of Agricultural Biotechnology, 9(2), 103-106.

Friends of the Earth (2008). Who benefits from GM crops? The rise in pesticide use. Agriculture and Food Issue112, . Amsterdam: Friends Earth International

Herring, R. J. (2007). Stealth seeds: Bioproperty, biosafety, biopolitics. Journal of Development Studies, 43(1), $130-157$.

Hossain, F., Pray, C., Lu, Y., Huang, J., Fan, C., \& Hu, R. (2004). Genetically modified cotton and farmers' health in China. International Journal of Environmental Health Research, 10, 296-303.

Hu, R., Pray, C., Huang, J., Rozelle, S., Fan, C., \& Zhang, C. (2009). Reforming intellectual property rights and the Bt cotton seed industry in China: Who benefits from policy reform? Research Policy, 38(5), 793-801.

Huang, J., Chen, R., Mi, J., Hu, R., \& Osir, E. (2009). Farmers' seed and pest control management for Bt cotton in China. In R. Tripp (Ed.), Biotechnology and agricultural development: Transgenic cotton, rural institutions and resource-poor farmers. London: Routledge.

Huang, J., Hu, R., Pray, C., Qiao, F., \& Rozelle, S. (2003). Biotechnology as an alternative to chemical pesticides: A case study of Bt cotton in China. Agricultural Economics, 29, 55-67.

Huang, J., Hu, R., Rozelle, S., Qiao, F., \& Pray, C. (2002). Transgenic varieties and productivity of smallholder cotton farmers in China. Australian Journal of Agricultural and Resource Economics, 46(3), 367-387.

Huang, J., \& Wang, Q. (2002). Agricultural biotechnology development and policy in China. AgBioforum, 5, 122-135.

Hurley, T., Secchi, S., Babcock, B., \& Hellmich, L. (2001). Bt corn and insect resistance: An economic assessment of refuges. Journal of Agricultural and Resource Economics, 26, 176-194.

James, C. (2007). Global status of commercialized biotech/GM crops: 2007. The International Services Acquisition of Agri-Biotech Applications (ISAAA) Brief No. 37: Preview. Ithaca, NY: ISAAA.

Kathage, J., \& Qaim, M. (2012). Economic impacts and impact dynamics of Bt (Bacillus thuringiensis) cotton in India. Proceedings of the National Academy of Sciences, 109(29), 11652-11656.

Kouser, S., \& Qaim, M. (2013). Valuing the financial, health and environmental benefits of Bt cotton adoption in Pakistan. Agricultural Economics, 44(3), 323-335.

Lalitha, N., Pray, C., \& Ramaswami, B. (2008). The limits of intellectual property rights: Lessons from the spread of illegal transgenic seeds in India. Discussion paper 08-06. Indian Statistical Institute.

Matteson, P., Gallagher, K., \& Kenmore, P. (1993). Extension of integrated pest management for plant hoppers in Asian irrigated rice. In R. Denno, \& T. Perfect (Eds.), Ecology and management of plant hoppers. London: Chapman \& Hall.

Ministry of Agriculture (MOA) (2005). The Office of Agricultural Transgenic Bio-safety Management. Collection of laws and regulations on agricultural transgenic biosafety management. Beijing: China's Agricultural Press.

Pemsl, D., Waibel, H., \& Gutierrez, A. (2005). Why do some Bt-cotton farmers in China continue to use high levels of pesticides? International Journal of Agricultural Sustainability, 3(1), 44-56. 
Pontius, J., Dilts, R., \& Bartlett, A. (2002). From farmer field schools to community IPM, ten years of IPM training in Asia. Jakarta, Indonesia: FAO Community IPM Programme.

Pray, C., Huang, J., Hu, R., \& Rozelle, R. (2002). Five years of Bt cotton in China: The benefits continue. The Plant Journal, 31(4), 423-430.

Pray, E., Huang, J., Hu, R., Wang, R., Ramaswami, B., \& Bengali, P. (2006). Regulating agricultural biotechnology: Economics and policy. Natural Resource Management and Policy, 30, 481-508.

Pray, C., Ma, D., Huang, J., \& Qiao, F. (2001). Impact of Bt cotton in China. World Development, 29, 813-825.

Pray, C., Prajakta, B., \& Ramaswami, B. (2005). The cost of bio-safety regulations: The Indian experience. Quarterly Journal of International Agriculture, 44(3), 267-289.

Pray, C., Ramaswami, B., Huang, J., Hu, R., Bengali, P., \& Zhang, H. (2006). Costs and enforcement of biosafety regulations in India and China. International Journal of Technology and Globalisation, 2(1/2), 137-157.

Qaim, M. (2003). Bt cotton in India: Field trial results and economic projections. World Development, 31(12), 2115-2127.

Qaim, M. (2009). The economics of genetically modified crops. Annual Review of Resource Economics, 1, 665-694.

Qaim, M. (2010). Benefits of genetically modified crops for the poor: Household income, nutrition, and health. New Biotechnology, 27(5), 552-557.

Qiao, F., Huang, J., Zhang, L., \& Rozelle, S. (2012). Pesticide use and farmers' health in China's rice production. China Agricultural Economic Review, 4(4), 468-484.

Sharma, D. (2004). GM food and hunger: A view from the South. New Delhi: Forum Biotechnology Food Security.

Smale, M., Zambrano, P., Gruère, G., Falck-Zepeda, J., Matuschke, I., Horna, D., et al. (2009). Measuring the economic impacts of transgenic crops in developing agriculture during the first decade approaches, findings, and future directions. IFPRI food policy review, no. 10. Washington, DC: International Food Policy Research Institute.

Yang, P., Iles, M., Yan, S., \& Jolliffe, F. (2005). Farmers' knowledge, perceptions and practices in transgenic Bt cotton in small producer systems in Northern China. Crop Protection, 24, 229-239. 